\title{
THE LAW AND POOR PEOPLE'S ACCESS TO HEALTH CARE
}

\author{
Norman L. CantoR*
}

Studies of the health care delivery system and patterns of utilization ineluctably point to the same basic conclusions-that "the poor are sicker than the nonpoor, and yet they use fewer health services." The statistics on sickness and need for services among poverty populations are staggering. Comparing families with annual incomes of less than $\$ 2,000$ to those with incomes of $\$ 7,000$ or more, the former suffer from heart conditions at a rate four times as high as the latter, they incur rheumatism and arthritis six times as often, and they suffer eight times as many visual impairments. ${ }^{2}$ And while such figures on chronic illness are partially attributable to the large numbers of elderly poor, extraordinary amounts of illness plague all segments of the poverty population. ${ }^{8}$ The data on usage of health services is no less conclusive in supporting the proposition that poor persons receive health care far less frequently than more affluent persons. For example, one study has indicated that children in families with incomes under $\$ 2,000$ average 1.6 physician visits per year compared with 5.7 visits for children in families with incomes over $\$ 7,000.4$ Thus, illness is not adequately treated and preventive services are seldom provided among the poor.

Although the facts on usage of services may be clear, the explanation is more difficult to pinpoint, for a multitude of factors probably account for the ultimate fact that poor persons do not receive sufficient services. There may be inadequate information or knowledge about the need for and availability of services, cultural attitudes influencing utilization, problems of alienation, language barriers, or simply physical distance barring usage of facilities. All of these elements may contribute to some degree, or in some instances. ${ }^{5}$ But the thesis of this article is that the existence

-A.B. 1964, Princeton University; LL.B. 1967, Columbia University. Assistant Professor, Rutgers University School of Law.

The research assistance of Laura L. Cantor, J.D. I97o, New York University School of Law, and Jared McDavit, a second-year student at Rutgers Law School, is gratefully acknowledged.

${ }^{2}$ Richardson, Poverty, Illness, and Use of Health Services in the United States, Hosprtars, July I, 1969, at 34. See also Muller, Income and the Receipt of Medical Care, in 3 Medical Care In Transimon 257 (Public Health Service Publication No. 1128, I967); James, Poverty as an Obstacle to Health Progress in Our Cities, 55 Am. J. Pub. Health 1757 (1965).

${ }^{2}$ Richardson, supra note I, at 35; see U.S. Dep't of Heasth, Education, and Welfare, Human Investiment Programs, Delivery of Healtith Services for the Poor 3 (ig67).

${ }^{3}$ See, e.g., Ribicoff, The Healthiest Nation Myth, SaturdaY Review, Aug. 22, 1970, at I8, 19, citing figures on the results of medical examinations of ghetto school children.

'Muller, supra note $\mathrm{I}$, at 262 . Moreover, the percentage of contacts at clinics and emergency rooms, as opposed to physicians' offices, is much higher among the poor. Richardson, supra note I, at 38; see Report of the Comantssion on the Delivery of Personal Health Services in New York City (Ig66) [hereinafter cited as PIEl Comanssion Report].

${ }^{5}$ See James, stupra note $\mathrm{x}$, at $1765-67$; Conway, The Beneficiary, the Consumer-What He Needs and Wants, 55 Am. J. Pub. HeAlth $x 782$ ( 1965$)$. 
of a dual system of health care stemming from the economic condition of poor persons -their low incomes-is the primary causal factor in their failure to obtain health care.

The inescapable fact is that low income creates an inability to obtain decent health services. Part of the reason is the geographical handicap of the ghetto, the lack of physical access to physicians and hospitals. While the trend to specialization among doctors and the concomitant loss of general practitioners have affected all health consumers, ${ }^{6}$ the poor have clearly been most affected. They simply cannot afford the services of specialists, ${ }^{7}$ and the remaining general practitioners tend not to practice among indigents. In one poverty area of the South Bronx, there were, in 1967 , four private physicians (two of them semi-retired) for a population of 45,000 . Similarly, the physical resources such as hospitals are sometimes accessible only by lengthy rides on public transportation. ${ }^{8}$ The resources readily available, if any, are the teeming outpatient departments and emergency rooms of municipal or county hospitals. Where private, voluntary hospital facilities are geographically available, the economic barrier to utilization may prove insurmountable. Particularly in the case of teaching hospitals, ${ }^{9}$ indigent patients are often denied admission unless they are "medically interesting" cases; $;^{10}$ in some instances where hospitalization is warranted, the private facility may refer, or "dump," the patient to a governmentally run institution. ${ }^{11}$ Medicaid's promise to make quality care available to the poor has gone largely unfulfilled. The unrealistic eligibility levels, the failure to enroll all those eligible, the inadequate scope of services in some states, and the dearth of cooperating providers have all combined to impede the improvement of access to health care by the poor.

This paper's aim is to analyze potential legal channels for improving this somber situation by increasing the access of poverty populations to health care. It might be more expeditious to eliminate the underlying economic handicap-for example, to provide universal and comprehensive health insurance through governmental channels. ${ }^{12}$ Indeed, it may eventually develop that litigation is unsuitable for effectively attacking the massive economic and physical misallocations which contribute

\footnotetext{
'See A. Somers, Some Basic Determinants of Medical Care and Health Policy, Mrrbank MEmonua Fund Q., Jan. I968, at I3.

${ }^{7}$ See Muller, supra note $I$, at 263 .

${ }^{8}$ A map of New York City health resources is enlightening on this point. See Bulz. Healty PoLIcY Advisory Councin, Nov, rg68, at 8.

Those institutions which train medical students, interns, or residents are here classificd as teaching hospitals. See generally M. CRICHTon, FIve PATIENTS (I970), describing the teaching function of Massachusetts General Hospital.

${ }^{10}$ See R. Duff \& A. Hollingshead, Sickness and Society I76-78 (1968).

${ }^{11}$ See Fisher v. County of Los Angeles, Civ. No. 68621 (Super. Ct., filed Jan. 12, 1970).

${ }^{12}$ See, e.g., Fein, The Case for National Health Insurance, SATURony Review, Aug. 22, 1970, at 27. Of course, a new financing mechanism would not be a panacea without an accompanying effort to reorganize the delivery system to make comprehensive services readily available to ghetto areas.
} 
to the access problem. ${ }^{13}$ Yet the goal-ready access to decent health care-is so important that every plausible channel of implementation deserves exploration.

\section{Constitutional Theories}

\section{A. Economic Discrimination}

As mentioned above, some medical facilities, most notably voluntary hospitals, may deny access to medically uninteresting indigent patients. A fiscal officer as well as a physician may screen the applicant for admission; failure to demonstrate ability to meet the likely hospitalization costs, or to provide a substantial deposit, may be grounds for rejection. ${ }^{14}$ Poverty lawyers have argued strenuously that such economic discrimination practiced by publicly funded institutions ${ }^{15}$ constitutes an invidious discrimination within the meaning of the fourteenth amendment's equal protection clause. ${ }^{16}$ Under this thesis, medical care cannot be denied on the basis of inability to pay. For example, in one case indigent patients argued that they could not be denied usage of a renal dialysis machine in a public hospital merely because they could not afford the extraordinary costs of the machine. ${ }^{17}$ They contended both that such a denial constituted a deprivation of life without due process of law and that the economic discrimination was invidious under the equal protection clause.

The argument that government is under a constitutional obligation to mitigate the disadvantages of indigent citizens is an extraordinary one in a society grounded on a free market theory and exhibiting the effects of unequal distribution of wealth. Yet the argument is not without support in modern constitutional doctrine. In at least two contexts-administration of criminal justice and voting-the Supreme Court has declared economic discrimination to be unconstitutional. ${ }^{18}$ In Griffin v. Illinois, the Court commented that "[i]n criminal trials a State can no more discriminate on

\footnotetext{
${ }^{13}$ See pp. 903-909 infra.

${ }^{24}$ DuFF \& Hollingshead, supra note io.

${ }^{20}$ Ever since the Civil Rights Cases, rog U.S. 3 (I883), a showing of "state action" has been a prerequisite to judicial intervention under the fourteenth amendment. Voluntary hospitals have sometimes been found exempt from constitutional requirements on the basis that they are "private." See, e.g., Shulman v. Washintgon Hospital Center, 222 F. Supp. 59 (D.D.C. 1963). However, the combination of governmental contacts from building loans, tax exemptions, research grants, and vendor payments should suffice to establish "state action" in private hospitals, and the recent judicial trend is in that direction. See Eaton v. Grubbs, 329 F.2d 710 (4th Cir. 1964); Note, State Action, State Law, and the Private Hospital, 62 Mrcr. L. REv. I433 (I964); 57 Kr. L.J. 297 (1969). See generally Silard, A Constitutional Forecast: Demise of the "State Action" Limit on the Equal Protection Guarantee, 66 Coums. L. REv. 855 (1966). For purposes of this article I am assuming that many private hospitals, as well as all public institutions, are subject to fourteenth amendment restrictions.

${ }^{10}$ See, e.g., Rose, The Duty of Publicly-Funded Hospitals to Provide Services to the Medically Indigent, 3 Clearinghouse Rev. 254 (I970).

${ }^{17}$ Butler v. Jones, Civ. No. 69-2799 (E.D. Pa. I969). No decision was ever obtained, as hospital officials eventually lowered the barriers for the indigent plaintiffs.

${ }^{18}$ See Harper v. Virginia Bd. of Elections, $3_{3}{ }_{3}$ U.S. $66_{3}$ (rg66) (poll tax); Douglas v. California, 372 U.S. 353 (1963); Griffin v. Illinois, 351 U.S. I2 (1956); Gardner v. California, 393 U.S. 367 (1969); Boddie v. Connecticut, 40I U.S. 371 (197I).
} 
account of poverty than on account of religion, race, or color."10 And in Harper $v$. Virginia Board of Elections, Justice Douglas added that "[1]ines drawn on the basis of wealth or property, like those of race ..., are traditionally disfavored."20

In both instances government was required to mitigate the effects of monetary fees conditioning access to governmental "services," either by supplying the desired "service" gratis to the indigent or by eliminating the economic barrier entirely. This thrust against economic discrimination and the handicaps of poverty was given further impetus by the 1969 decision in Shapiro v. Thompson. ${ }^{21}$ There, in considering a challenge to a state residency requirement restricting eligibility for welfare benefits, the Court indicated that only a compelling state interest would justify a discrimination affecting receipt of subsistence benefits and impinging on the right to travel freely among the states. ${ }^{22}$ Thus, it appeared that, at least, the traditional "mere rationality" standard of equal protection would be replaced by a strict scrutiny test in cases affecting the ability of impoverished citizens to obtain the necessities of life.

However, the thesis that economic discrimination is basically invidious and that the poor cannot be denied access to governmentally-financed benefits (such as health care) has been dealt a body blow by the Court's recent equal protection decision in Dandridge v. Williams. ${ }^{23}$ There, welfare recipients attacked the constitutionality of state "maximum grant" regulations. Under these provisions, states placed limitations on dollar amounts which would be distributed to large families, regardless of increased needs of such families. Thus, in Maryland for example, the maximum grant was $\$ 250$ per month, and families with ten or twelve children could receive no more than families with six children. Plaintiffs had successfully challenged the regulation before a three-judge district court panel on the basis that discrimination according to family size rather than need constituted an invidious classification in violation of equal protection guarantees. ${ }^{24}$ The Supreme Court reversed, finding a rational relationship between the maximum grant regulation and two legitimate legislative purposes-encouragement of employment and avoidance of adverse income discrepancies between welfare families and families of the working poor. ${ }^{25}$ That the regulation encouraged only welfare recipients with large families to seek employment, even though these recipients may be the least likely to be able to undertake

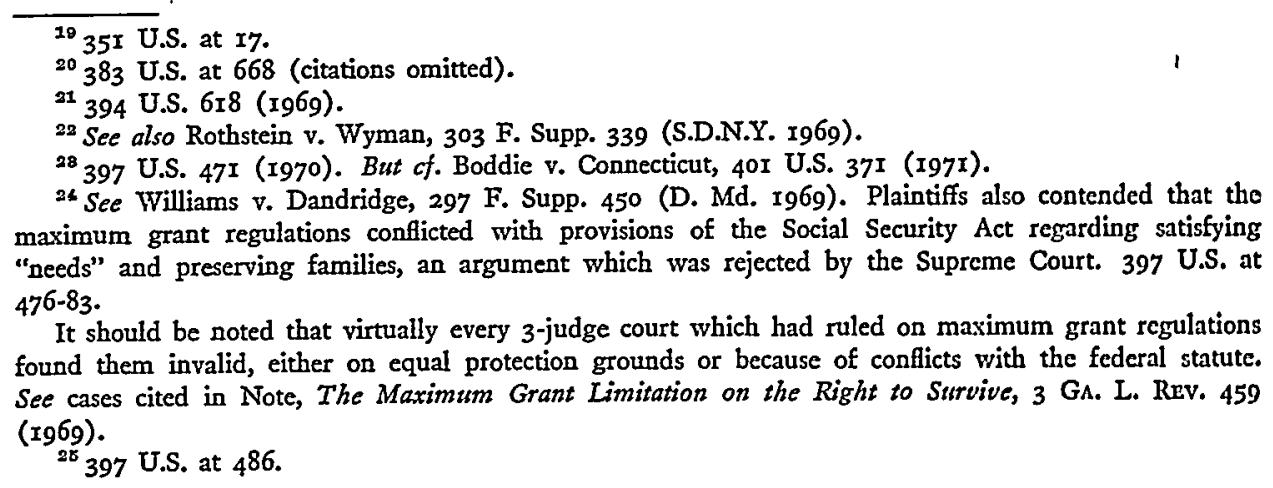


work, and that the regulation did not demonstrably tie welfare incomes to incomes of the working poor, ${ }^{26} \mathrm{did}$ not affect the Court's finding of a rational basis for the regulation.

Yet the shocking aspect of Dandridge is not so much the result as the calculated manner in which the majority opinion undermined the foundation of the economic discrimination theory. In the first place, the Court abjured the "strict scrutiny" or "compelling interest" standard $\mathrm{d}^{27}$ in favor of the more traditional "reasonable basis" test. $^{28}$ While recognizing that distribution of welfare benefits "involves the most basic economic needs of impoverished human beings," the Court insisted on treating the Dandridge problem as a customary "economic regulation" case. ${ }^{29}$ Shapiro $v$. Thompson was relegated to a footnote, ${ }^{30}$ and no mention was made of the economic discrimination cases. More importantly, the majority opinion stressed the fiscal difficulties of the state, its limited resources, and the concomitant legislative need to set careful limits on benefit levels. ${ }^{31}$ This solicitude for state economic interests appears, as will be explained more fully, incompatible with an expansive theory of equal protection which attacks economic discrimination.

This is not to say that the theory of invidious economic discrimination is dead. After all, Dandridge in one sense is not an economic discrimination case. The

\footnotetext{
${ }^{20} \mathrm{Id}$. at 524-27. (Marshall, J., dissenting).

${ }^{27}$ See Shapiro v. Thompson, 394 U.S. 618, 638 (1969).

${ }^{28}$ See, e.g., McGowan v. Maryland, 366 U.S. 420, 426 (196x); Developments in the Law-Equal Protection, 82 HARv. L. REv. 1065 (Ig69).
}

${ }^{20} 397$ U.S. at 485 . Compare the following statement in Rothstein v. Wyman, 303 F. Supp. 339, 346-47 (S.D.N.Y. I969) (footnotes omitted), where a 3-judge court applied a "compelling interest" standard in reviewing an equal protection challenge to a welfare regulation:

"Receipt of welfare benefits may not at the present time constitute the exercise of a constitutional right. But among our Constitution's expressed purposes was the desire to insure domestic tranquility' and 'promote the general Welfare.' Implicit in those phrases are certain basic concepts of humanity and decency. One of these, voiced as a goal in recent years by most responsible governmental leaders, both federal and state, is the desire to insure that indigent, unemployable citizens will at least have the bare minimums required for existence, without which our expressed fundamental constitutional rights and liberties frequently cannot be exereised and therefore become meaningless. Legislation with respect to welfare assistance, therefore, like that dealing with public education, access to public parks or playgrounds, or use of the mails, deals with a critical aspect of the personal lives of our citizens, whether such assistance be labelled a 'right,' 'privilege' or 'benefit.' ... Its importance is magnified by the defenseless and disadvantaged state of the class of citizens to which it relates, who are usually less able than others to enforce their rights. It can hardly be doubted that the subsistence level of our indigent and unemployable aged, blind and disabled involves a more crucial aspect of life and liberty than the right to operate a business on Sunday or to extract gas from subsoil. We believed that with the stakes so high in terms of human misery the equal protection standard to be applied should be stricter than that used upon review of commercial legislation and more nearly approximate that applied to laws affecting fundamental constitutional rights. Poverty is a bitter enough brew. It should not be made even less palatable by the addition of unjustifiable inequalities or discriminations. It must not be forgotten that in most cases public assistance represents the last resource of those bereft of any alternative. Equity (the state or quality of being equal, derived from the latin aequitas), should least of all be denied the poor."

${ }^{50} 397$ U.S. at 484 n.I6. Justice Stewart's opinion merely notes that Shapiro, where a compelling interest formula was applied to a welfare regulation, involved interference with the constitutional right of interstate travel, which (unlike welfare payments) he considered guaranteed by the Bill of Rights.

${ }^{31} 397$ U.S. at 487 . 
allegedly invidious classification there related to family size; the welfare recipients, whether in large families or small, were similarly situated as far as initial economic status was concerned. While the invidious discrimination lay in the allocation of monetary benefits, the scheme of distribution did not depend on wealth and did not vary according to the economic status of the recipients.

Yet in another sense Dandridge is in fact an economic discrimination case. The distribution of benefits did not vary according to family need; the result was to create classes of people with unequal economic status despite similar personal needs. If there is a governmental obligation to assure affirmatively that certain financially deprived citizens do not suffer greater adverse consequences from their economic straits than other persons with similar needs, the distribution scheme in Dandridge accomplished the antithesis of what is required. The maximum grant regulation literally created discrepancies in wealth despite citizens' similar needs.

Further, the Court's concern for state fiscal resources reveals a prime obstacle to widespread judicial invocation of the economic discrimination theory-the fear of massive judicial intervention in the allocation of government resources. The redress of economic imbalances in any area of contemporary life inevitably involves tremendous expenditures. Take health care as an example. If the invidious discrimination consists of governmental allocation of services so that poor persons are deprived of health care, alleviation of this condition requires enormous sums for acquisition of facilities, equipment, and staff. Even if the discrimination consists only of unequal systems for rich and poor, elimination of the discrepancies requires huge outlays. The decision to allocate governmental revenues is traditionally a legislative function; indeed, it is an integral aspect of the separation of powers. The judicial hesitancy to establish an equal protection doctrine which impels massive governmental expenditures is therefore understandable, even if in opposition to desirable social goals.

Underlying this hesitancy is the realization that the economic discrimination theory is potentially applicable to a host of de facto economic bars extant in a free enterprise society. A cursory look at governmental services alone indicates that economic status closely affects access to licenses, toll roads, amusement areas, universities, public tranportation, and public utility services, among other things. Eliminating economic bars or disadvantages in any or all of these areas would be enormously expensive. Along with this basic fact, the dismal economic conditions of urban governments, and even some state governments, must be considered. Again, the judicial hesitancy to direct large expenditures is not difficult to fathom.

Another obstacle to judicial expansion of the economic discrimination theory is inability to enforce the doctrine once established. How does a court compel compliance with a mandate that a local government provide a school in an economically deprived neighborhood $?^{32}$ Is the judiciary willing to confront executive and legislative

\footnotetext{
${ }^{32}$ Cf. U.S. CoNsr. amend. XI.
} 
intransigence toward decrees ordering elected representatives to expend vast sums on judicially designated objects? ? $^{33}$ In the cases involving economic discrimination in the administration of criminal justice, there was a built-in sanction-the release of indigent prisoners if government failed to provide the requisite items (counsel, transcripts, and so forth). No such ready enforcement mechanism is available if a court orders construction of a school or hospital in an impoverished neighborhood.

It might be argued that health care is so intimately related to existence itself that the subject deserves special consideration. In other words, economic barriers might be constitutionally impermissible in the case of health services but not in other fields (education, transportation, and the like) less integrally tied up with life and health. This seems a rather spurious argument. How can health care be realistically distinguished from transportation, which affects ability to earn a living, or plain absence of adequate welfare benefits, which affects ability to subsist? Indeed, in states where no separate medical benefits program exists, people may depend on general welfare benefits for medical care as well as food and shelter, and a decision to constitutionally compel payments for indigents' medical care would automatically increase basic welfare payments in those states.

From the above observations, it appears that the theory that economic status precluding access to health care imposes affirmative governmental obligations to remedy the de facto discrimination is not likely to provide the health facilities or increased access needed to end the dual system of health care. The law in this area will not be static. Equal treatment in the administration of criminal justice is an established principle, and extension of the principle to the entire court system, civil as well as criminal, is likely to ensue. ${ }^{34}$ But extension of the theory to transportation, education, health care, and the like is not on the immediate horizon. Solutions to the health care crisis must be sought elsewhere.

\section{B. The Right to Life}

An alternative constitutional argument for requiring government to furnish health care has been advanced which avoids some of the pitfalls of the equalprotection/economic-discrimination theory. First articulated by Professor Edward Sparer ${ }^{35}$ and carefully elaborated by Professor Frank Michelman, ${ }^{36}$ the "right-tolife" notion posits an affirmative governmental obligation to furnish citizens with the minimum "necessities" of life-shelter, income sufficient to procure food and clothes, and health care. The constitutional foundation is found primarily in the economic discrimination cases cited above. ${ }^{37}$ However, the constitutional handle is not so much

\footnotetext{
${ }^{33}$ Cf. Powell v. McCormack, 395 U.S. 486 (I969).

${ }^{34}$ See Note, The Right to Counsel in Civil Litigation, 66 Colom. L. Rev. 1322 (1966); Note, The Indigent's Right to Counsel in Civil Cases, 76 YALE L.J. 545 (I967); Boddie v. Connecticut, 40I U.S. 37 I (I97I).

${ }^{85}$ Shenker, Guarantee of 'Right to Live' is Urged, N.Y. Times, Sept. 28, 1969, at 40, col. 4.

${ }^{30}$ Michelman, Foreword: On Protecting the Poor Through the Fourteenth Amendment, in The Supreme Court, rg68 Term, 83 HARv. L. Rev. 7 (1969).

${ }^{37}$ See notes $x$ 8-20 supro and accompanying text.
} 
discrimination against persons without wealth as it is "deprivation" of basic necessities. "[T] he only inequality turns out to be that some persons ... are suffering from inability to satisfy certain 'basic' wants which presumably are felt by all alike."38 Occasionally the same "right-to-life" argument is framed in due process rather than equal protection terms. ${ }^{33}$ Under the latter formulation it becomes a deprivation of life or liberty without due process if a state permits its indigents to die from starvation, exposure to the elements, or absence of medical assistance. But whether the argument is framed in equal protection or due process language, its thrust is that citizens must be provided with the necessities for subsistence, as the exercise of fundamental civil liberties depends initially on the ability to survive.

As noted, the right-to-life approach does avert some weaknesses of the economic discrimination theory in combating the handicaps of poverty. ${ }^{40}$ The right-to-life formulation avoids obsession with absolute equality of treatment, an element which is simply not realistic in a free market economy. It is futile to hope, for example, that government can provide counsel for the indigent equivalent in skill to the high-priced talent available to the rich client; the obligation must instead be to furnish competent counsel. Similarly, under the right-to-life approach there would be no temptation to achieve equality by bringing everyone down to the lowest common denominator-even if that means no care; the obligation to avoid economic discrimination in government-supported activities, such as higher education for example, can be too easily fulfilled by abolishing all state universities.

At the same time, the right-to-life approach suffers from some of the same infirmities as the economic discrimination argument. The result of invoking minimum protection rather than equal protection is still massive judicial reallocation of governmental resources. The judiciary's natural reluctance to fix over-all priorities persists. ${ }^{11}$ Similarly, doubt persists about the judiciary's ability to enforce a minimum protection decree in the face of limited public resources. Even if fiscal resources are available, the justiciability of the minimum-protection or right-to-life requirement would be in grave doubt. That is, are courts equipped to determine what constitutes minimum shelter, minimum education, minimum health care, or the level of income needed for basic food and shelter? Can courts decide whether health care is to be upgraded by the addition of physicians or equipment or physical plant? And if the answer is physicians, will the courts rule on the qualifications of the personnel obtained? The only objective factor which courts are equipped to measure is money. Yet requiring the expenditure of funds at a given level by no means assures that the end product will be a satisfactory level of health care.

The viability of the right-to-life, minimum-protection analysis is in considerable

\footnotetext{
${ }^{83}$ Michelman, supra note 36 , at I3 (italics omitted).

${ }^{80}$ Graham, A Poor Person's Right to Life, Liberty and Property, x7 Wetrarz L. Buxl. 28 (1969).

${ }^{10}$ See Michelman, supra note 36, at $x$ r.

${ }^{41}$ Cf. Note, Scarce Medical Resources, 69 Colum. L. Rev. 62x, 689 (I969), where the authors discuss the difficulties attached to setting priorities among "competing necessities" such as health care and housing.
} 
doubt as a result of the Supreme Court's recent decision in Rosado $v$. Wyman.2 Rosado was an action by New York welfare recipients challenging a state reduction in the "standard of need" for determining welfare eligibility. By eliminating items previously included in computing the state's standard of need, New York had reduced benefits to recipients by almost $\$ 40$ million. The claim was that New York's reduction contravened a federal requirement that states re-evaluate their standards of need to reflect cost of living increases. The Supreme Court, in an opinion by Justice Harlan, held that the state had in fact impermissibly lowered its standard of need in violation of the federal requirement. However, the court simultaneously ruled that the state could reduce the level of actual assistance paid, regardless of the standard of need, in order to combat budgetary pressures. Further, there was no barrier to state payments according to average needs of recipients even if the particularized needs of some individuals would not be met. ${ }^{43}$ The state was not constitutionally barred from pursuing administrative efficiency even if the net assistance to some families would be reduced below already insufficient levels.

Rosado thus hamstrings the movement toward establishment of a constitutional right to life which would encompass the provision of basic health care. Unless health care is more integrally related to existence than food or shelter, it will be difficult to evade the implications of the decision. When the moment arrives that the Court undertakes through constitutional interpretation to end the most crippling effects of poverty, the mechanism may well be minimum protection rather than economic discrimination. But the immediate prospects are not bright for a constitutionally grounded solution to the inability of poor persons to obtain basic health services.

\section{II}

\section{Common Law Obligations}

\section{A. Emergency Care}

One of the most distressing hospital practices, common to urban areas, is the "dumping" of indigent, medically "uninteresting" patients into already undermanned governmental facilities. ${ }^{44}$ A private, voluntary facility will divert ambulances to nearby municipal or county hospitals, either without rendering any treatment or after giving perfunctory attention; eventually the ambulance drivers are conditioned to delivering patients from poverty neighborhoods directly to the governmental institutions. Similarly, many private voluntary hospitals may redirect indigent ambulatory patients needing inpatient care to overcrowded governmental institutions; exceptions would likely be made only for medically interesting cases

\footnotetext{
4397 U.S. 397 (1970).

c3 Id. at $4 \mathrm{rg}$.

"See Fisher v. County of Los Angeles, Civ. No. 6862I (Super. Ct., filed Jan. 12, x970); Jones v. City of New York, I34 N.Y.S.2d 779 (Sup. Ct. I954); New Biloxi Hospital, Inc. v. Frazier, 245 Miss. I85, I46 So. $2 \mathrm{~d} 882$ (I962).
} 
and perhaps for some Medicaid patients. The consequences are occasionally extreme, for patients have been known to die en route from private hospitals to municipal facilities. ${ }^{45}$

To prevent these unnecessary deaths alone, it would be important to establish unequivocally an obligation of all hospitals to treat all emergency cases. But the issue assumes added importance when considered in light of modern patterns of hospital usage. A significant phenomenon of contemporary medical care is the evolution of the hospital emergency room into a full-fledged outpatient clinic. Such facilities have become, in effect, twenty-four-hour dispensaries-the place of first resort for an entire spectrum of problems from the coughing child to the critically injured accident victim. Hospital administrators may object to this usurpation of the emergency room's intended function, ${ }^{46}$ but the emerging patterns of usage and the public's determination are clear. The number of emergency room visits has increased much faster than either inpatient admissions or outpatient visits, and studies indicate that the trend will continue at an increased rate. ${ }^{47}$ Moreover, studies confirm that growth in volume has been accompanied by a trend away from genuine emergency cases toward basic health care. ${ }^{48}$ Nonemergency cases, involving minor illnesses and injuries, have been responsible to a substantial degree for the transformation of the emergency room into an ad hoc clinic. This is not surprising, considering that to many patients any complaint may become an emergency if they cannot locate a physician or, as is more often the case with applicants for emergency room care, they cannot afford a private physician. Changing emergency room usage is also related to the gradual development of the modern urban hospital into the focal point of all health services. ${ }^{49}$ The hospital represents the institutionalization of health care delivery, offering complex and costly equipment operated by skilled personnel. Along with centralization of care, the public must deal with the pressing shortage of physicians, the disappearance of the traditional family doctor, and the disinclination of physicians to make house calls. Moreover, the schedules of medical offices and outpatient departments do not usually coincide with the needs of the working poor. The result of these processes has been the public's general acceptance of the idea

\footnotetext{
${ }^{4}$ This conclusion is based upon personal conversations with interns and medical students in New York City, as well as on information broadcast on television documentaries prepared by NET and CBS during 1970.

${ }^{10}$ See generally The Emergency Department Problem: An Overview, x98 J.A.M.A. 380 (1966).

${ }^{47}$ E.g., The Nation's Hospitals: A Statistical Profile, Hospritals (Gume Issue), Aug. x, 1966, pt. 2, at 427 et seq. Public Health Service projections for the decade $1960-70$ indicated increased general hospital use of $8 \%$ compared to a $79 \%$ growth in emergency room visits. Public HenLth Service, Hospital Outpatient Services: Facts and Trends I4-I5 (Hospital and Medical Facilities Serics No. 930-C-6, I966).

${ }^{48}$ For example, a I96x study of 300 hospitals indicated that $42 \%$ of all emergency visits were nonemergent. Skudder, McCarroll \& Wade, Hospital Emergency Facilities and Services, $A$ Survey, 46 Burl. Am. Coll. Surgeons 44 (xg6r). See also Stichter, Medical Staffing of Emergency Rooms, 62 OHio StAтz MED. J. 600 (I966); The Emergency Department Problem: An Overview, supra note 46.

${ }^{\circ}$ See, e.g., Knowles, The Teaching Hospital: Historical Perspective and a Contemporary Vietv, in Hospitals, Doctors and the Public INTEREst I, 13-I5 (J. Knowles ed. 1965).
} 
that hospital facilities, especially emergency facilities, should be available for all kinds of illnesses and injuries, at any time and without appointment.

In light of these developments, it becomes all the more important to guarantee ready accesss of indigent patients to emergency room facilities. The first step in this process is to remove the legal uncertainty surrounding the issue of a hospital's obligation to treat and care for genuine emergency cases. Establishment of this narrow principle would likely have marked repercussions on operation of emergency room facilities generally. In the first place, the legal definition of "emergency" can probably not be restricted to cases where death is imminent or even likely should treatment not be provided. For the common notion of emergency includes the preservation not just of life but of body and health, where these are seriously endangered. ${ }^{50}$ Once a clear duty to treat emergencies is established, hospitals would be risking liability every time treatment was denied. Certainly the practice would be to have a physician make a careful examination before considering transfer; and if a patient articulates severe complaints, there is a potential "emergency" which is not likely to be ignored. Hopefully, physicians would be less inclined to dismiss the "junk" case-the sore throat, severe headache, or abdominal pain patient-without examination and treatment, and, once treatment is undertaken, it cannot be terminated (without malpractice exposure) in a manner which would worsen the condition of the patient. Finally, confirmation of a clear obligation to treat all emergency cases should encourage more liberal attention to all presenting cases and the reorganization of the emergency room into an outpatient facility capable of both emergency and nonemergency care at all times.

The law in this area is gradually progressing toward the desired goal of required treatment of all emergency cases. Traditionally, a hospital was under no duty to maintain emergency services or to provide emergency care to the general public. This was but one aspect of the underlying proposition that a hospital may reject any patient that it does not choose to treat. ${ }^{51}$ However, the courts, in the context of emergency care, have constantly striven to avoid the harsh consequences of allowing hospitals such broad prerogatives; they have literally strained to impose liability for the callous disregard of humanity implicit in the rejection of emergency cases. The theory most commonly used to circumvent the basic "no-duty" rule is that of "gratuitous undertaking." According to this theory, the hospital's exercise of control over a patient imposes an obligation to act reasonably, including a duty not to transfer or turn the patient away if such rejection would worsen the condition of the patient or inflict further harm. Under this standard a hospital could never discharge a patient, once some control is exercised, without furnishing or procuring

\footnotetext{
${ }^{50}$ See New Biloxi Hospital, Inc. v. Frazier, 245 Miss. I85, I97, I46 So. 2d 882, 887 (I962); Williams v. Hospital Authority, II9 Ga. App. 626, I68 S.E.2d 336 (I969).

${ }^{E 1}$ Birmingham Baptist Hospital v. Crews, 229 Ala. 398, I57 So. 224 (I934); 62 Colum. L. Rev. 730 (Ig62); 4 I C.J.S. Hospitals $\$ 8$ (I944).

E2 Restatemient (Second) of Torts $\$ 323$ ( 1965 ).
} 
sufficient care to alleviate the emergency condition. ${ }^{53}$ In one case a mere wait on a stretcher in the emergency room was sufficient "control" to trigger the hospital's obligation. ${ }^{54}$ However, it is apparent that under the gratuitous undertaking theory a hospital may avoid liability by rejecting an applicant outright without exercising any form of control.

A more promising theory, then, is one which views the operation of emergency facilities as a standing invitation to the public to utilize the emergency services, justifying public reliance on the constant availability of emergency treatment. ${ }^{65}$ The seminal case in this area is Wilmington General Hospital v. Manlove. ${ }^{60}$ There, plaintiff's four-month-old child had been brought to the hospital suffering from diarrhea and a severe fever; the hospital turned the parents and child away without even examining the child. The baby died the same day from bronchial pneumonia. The Delaware Supreme Court upheld a tort action against the hospital, not on the theory that a hospital must normally care for emergency cases but rather on the basis that the parents had relied to their detriment on the established custom of the hospital to render emergency care. The hospital had held itself out as offering emergency help, and reliance on that representation presumably resulted in detrimental foregoing of alternative help. The same theory recently applied in a Missouri case to impose liability on a hospital which had rejected a frostbite victim because of inability to pay a $\$ 25$ deposit.57

The theory that maintenance of emergency facilities constitutes an implied invitation to the public probably suffices to impose liability in the vast majority of desired circumstances. However, the notion that this theory depends on detrimental "reliance" is a subterfuge and might readily be abandoned. Suppose a hospital were the only medical facility in a given area, so that reliance could not be said to have worsened the patient's chances of recovery since there was no alternative facility available. Liability would still be appropriate, despite the absence of detrimental reliance, simply because the presentation of a seriously ill individual to an institution equipped to alleviate human distress is sufficient to trigger a "humanitarian" obligation which must be enforceable, if necessary, in a court of law.

Public and voluntary hospitals, organized as charitable institutions, operate for the very purpose of healing the sick and injured. To permit such an institution to deny its fundamental purpose when confronted with an emergency case is intolerable. A similar sentiment was recently expressed by a Georgia court in upholding

\footnotetext{
${ }^{83}$ See New Biloxi Hospital, Inc. v. Frazier, 245 Miss, 185, 146 So. $2 d 882$ (I962); Corten v. Harbor Hospital, 279 App. Div. 673, I08 N.Y.S.2d 352 (195I).

ss Methodist Hospital v. Ball, 50 Tenn. App. 460, 362 S.W.2d 475 (196r).

so See Bernstein, Law in Brief, Hospitals 64 (1970).

${ }^{83} 54$ Del. 15, I74 A.2d 135 (I961). See 3 I U. Cin. L. Rev. 183 (I962); I 4 STAN. L. Rev. 9 Io (I962).

${ }^{57}$ Stanturf v. Sipes, 447 S.W.2d 558 (Mo. 1969). According to another recent case, imposition of a duty to treat an emergency does not necessarily mean that the patient must be admitted as an inpatient so long as the treatment given alleviates the immediate crisis. See Joyner v. Alton Ochsner Medical Foundation, 230 So. $2 d$ 913 (La. Ct. App. 1970).
} 
the right of a plaintiff to sue a public hospital for failure to render care when the plaintiff appeared with a broken arm, visibly in pain, and "in a state of traumatic injury." The court commented,

To say that a public institution which has assumed this duty [emergency care] and held itself out as giving such aid can arbitrarily refuse to give emergency treatment to a member of the public . . . is repugnant to our entire system of government. ${ }^{59}$

Similar humanitarian feelings underlie the statutory measures which impose a duty upon both public and private hospitals which maintain emergency departments to furnish emergency treatment to anyone who applies, regardless of ability to pay. ${ }^{60}$ Yet rather than wait for gradual legislative efforts to cope with the unfortunate common law history, it is time for frank judicial recognition that the modern emergency facility has a firm legal obligation to fulfill its purpose by rendering "emergency" assistance to all.

\section{B. Hospitals as Public Service Institutions}

Provision of emergency care without regard to economic circumstances would constitute a significant step toward assuring universal access to health services. Yet full implementation of the goal would depend on guaranteed access to the full range of care, in addition to emergency services, encompassed by modern medicine. This would include preventive care, a spectrum of outpatient services, and inpatient services. The prospects of judicially compelling the construction of the necessary new facilities are bleak. But the courts might legitimately be asked to assure access of poor persons to existing facilities, at least those facilities erected to care for the general public or the sick poor. It is not out of the question to speak, for example, of a common law obligation of hospitals-at least the governmental or voluntary ones-to offer services without excluding the indigent.

The mass of legal history is admittedly contrary to the above proposition. Traditionally, a hospital has been under no obligation to extend its services to a patient it did not desire to serve. Despite the critical social importance of their functions, neither physicians nor hospitals have been customarily compelled to render free care. ${ }^{61}$ This rule has been especially rigid in jurisdictions which preserved the notion of voluntary, nonprofit institutions as private entities. ${ }^{62}$ As succinctly stated in one case, "Defendant is a private corporation, and not a public institution, and owes the public no duty to accept any patient not desired by it. In this respect it is

\footnotetext{
${ }^{58}$ Williams v. Hospital Authority, Irg Ga. App. 626, I68 S.E.2d 336 (I969).

${ }^{00}$ Id. at 627 , I68 S.E.2d at 337 .

${ }^{00}$ See Ariz. Rev. Stat. ANN. $\$$ II-297A (I956); CaL. Health \& Safety Code $\$$ I 407.5 (West Supp. r969); IIl. Rev. Stat. ch. III1/2, $\$ 86-87$ (Ig67); N.Y. Pub. Health Law $\$ 2806$ (McKinney Supp. 1969); Pa. Stat. ANn. tit. 35, § 2 (1964).

${ }^{1}$ See J. RICHARDSON, DOctors, LAWYERS, AND THE COURTS Io (I965).

${ }^{03}$ See, e.g., Stanturf v. Sipes, 224 F. Supp. 883 (W.D. Mo. 1963), affd, 335 F.2d 224 (8th Cir. 1964), cert. denied, 379 U.S. 977 (1965).
} 
not similar to a public utility." serve persons who were unable to pay for the service.

Yet hospitals were historically founded to meet the medical needs of the sick poor. ${ }^{64}$ In accordance with the philanthropic motivations of their founders, the charters of innumerable private "charitable" hospitals explicitly required the rendering of care to all patients who needed assistance, including the sick poor. ${ }^{05}$ Such institutions were sustained by the charitable contributions of the public at large. In many instances fiscal burdens have gradually impeded continuation of the hospital's charitable function and in some instances provoked complete discontinuance of "free" care. ${ }^{60}$ But the original intent of establishing the voluntary hospital as a haven for the sick poor is clear.

At the same time as the focus of hospital patient care was shifting from the poor population toward the general public, the source of hospital funding was changing. Massive infusions of public monies began, ending the reliance on private contributions and eventually reaching the point where today approximately fifty per cent of private hospitals' operating funds are derived from governmental sources. ${ }^{\text {ot }}$ The over-all impact of governmental contributions is even greater, including not just Medicaid, Medicare, and local welfare funds but hospital construction loans, research grants, and tax exemptions as well. Increased governmental input and growth of the hospital as the focal point of health care for the general public have combined to promote awareness of the social importance of the modern hospital. In part, this awareness has been reflected by closer regulation and licensing of hospital facilities. ${ }^{08}$ Another result has been general recognition of the modern hospital as a "social utility . . . accountable to the community for the use it makes of the resources that the community entrusts to it."

To some extent, the public nature and function of the modern hospital has been recognized in evolving legal doctrine. This judicial development has come primarily in cases regulating the prerogatives of private hospitals and medical societies to exclude or oust medical practitioners. ${ }^{70}$ The leading case is Griesman $v$. Newcomb

\footnotetext{
${ }^{63}$ Birmingham Baptist Hospital v. Crews, 229 Ala. 398, 399, 157 So. 224, 225 (1934); see Scarce Medical Resources, supra note 4I, at 628-29.

ot See Knowles, supra note 49, at I3-I5; M. Herserey, Labor Relations in Hospitals in the Private SEcror 217-19 (Industrial Relations Research Ass'n, 1969).

${ }^{B E}$ Stanturf v. Sipes, 224 F. Supp. 883, 885-86 (W.D. Mo. 1963). See generally I. Belknap \& J. Steinle, The Community and Its Hospitals 9 (1963).

${ }^{86}$ See Note, Working Rules for Asstring Nondiscrimination in Hospital Administration, 74 YaLe L.J. I5x, I56 n.32 (I964).

${ }^{67}$ PIEL CoMmission RePORT, supra note 4, at 59.

${ }^{68}$ See, e.g., Iowa CodE ANN. $\$ \$$ I35B.I-.32 (Supp. I970); ANN. LAws Mass. ch. III $\$ \$ 7$ I-72 (Supp. I966); N.J. Stat. ANN. $\$ 30:$ II-I (1964).

${ }^{60}$ Piel Commission Report, supra note 4, at 60; see 57 Ky. L.J. 297 (I969).

${ }^{70}$ See, e.g., Falcone v. Middlesex County Medical Soc'y, 34 N.J. 582, r7o A.2d 79r (196r); Pinsker v. Pacific Coast Soc'y of Orthodontists, I Cal. 3d 160, 460 P.2d 495, 8r Cal. Rptr. 623 (I969); Burkhart v. Community Medical Center, 432 S.W.2d 433 (Ky. I968); 57 Kx. L.J. 297 (1969).
} 
Hospital. ${ }^{71}$ There the plaintiff, a licensed physician, challenged the by-laws of defendant hospital which barred his admission to the medical staff because he was a graduate of an osteopathic rather than a medical school. The hospital defended on the basis that as a private, nonprofit institution it had complete discretion-free of judicial interference-to fix its requirements for staff membership. In a landmark decision, the New Jersey Supreme Court unanimously invalidated the disputed by-law as an arbitrary exclusion in violation of public policy and the hospital's fiduciary obligations to the general public. The court found the hospital "private" in the sense of being nongovernmental but "hardly private in other senses."72 The hospital's chartered dedication to the vital public use of serving the sick and injured and the governmental contributions of funds and tax exemptions belied the notion of a private entity. As "hospitals are operated not for private ends but for the benefit of the public, $" 73$ they receive their powers impressed with a public trust"fiduciary powers to be exercised reasonably and for the public good."74 Precedent for judicial intervention on a public trust theory was found in the traditional imposition of common law duties upon innkeepers, common carriers, and similar private enterprises with extraordinary impact on the public. ${ }^{75}$ In effect, the hospital was treated by the court as a species of public utility; the context, of course, did not involve a duty to serve without charge.

Another sensitive articulation of the "public trust" or "social utility" approach to hospitals can be found in the lower court opinion in the Wilmington General Hospital $^{76}$ case, discussed above in connection with emergency care. At issue was a private hospital's liability for failure to render emergency assistance to a patient who was apparently able to pay for the service but had no physician's admission slip. The lower court found a common law duty to render such care not because of patients' reliance on the hospital's practice of providing emergency services but rather because of the "quasi-public" nature of the institution. "The hospital meets a public need, offers a public benefit, promotes the public welfare."77 According to the court, these public functions, in combination with tax exemptions and direct government appropriations for indigents' care, constituted "public aspects" which warranted imposition of extraordinary obligations to benefit the community at large.

In short, the public trust concept of Griesman and Manlove provides a doctrinal foundation for imposing a common law duty on nonproprietary hospitals to serve the poor. Such a development would entail a radical departure from the historical

\footnotetext{
${ }^{71} 40$ N.J. 389, I92 A.2d 8r7 (1963).

${ }^{23} I d$. at 396, A.2d at $82 \mathrm{I}$.

${ }^{73} \mathrm{Id}$. at $403, \mathrm{Ig} \mathrm{A} .2 \mathrm{~d}$ at 825 .

${ }^{71}$ Id. at 402 , r92 A.2d at 824 .

${ }^{75}$ See also Falcone v. Middlesex County Medical Soc'y, 34 N.J. 582, 17o A.2d 79 I (r96I).

${ }^{70}$ Manlove v. Wilmington Gen. Hosp., 53 Del. 338, I69 A.2d 18 (Super. Ct.), affd, 54 Del. I5, I74 A.2d 135 ( $196 \mathrm{r}$ ).

${ }^{77}$ Id. at 343,169 A.2d at 21 .
} 
permissive attitude toward hospitals' admissions policies. ${ }^{78}$ Yet the development would be no more innovative, in its theory, than evolution of the labor union's duty of fair representation or the common law remedy for invasion of the right to privacy. The hospital's obligation, like the union's duty, would be grounded solidly on fundamental dictates of justice and public policy. Just as the courts could not ignore the perilous status of the minority worker, they may not be able to tolerate the spectre of human beings denied access to health care because of poverty. The question remains whether, after examining the practical implications of the proposed doctrine, wisdom would dictate that the courts establish a common law right of access to health facilities.

To some extent the public trust formulation of hospital obligations actually avoids some practical problems raised by the minimum-protection or right-to-life argument discussed above. For example, there would be no need to judicially determine and regulate minimum standards of care. Problems of enforcement would be diminished; right of access would be assured by injunctive relief against hospital administrators or by damage actions against hospitals for failure to honor their obligations. Nor would a common law right of access, enforceable against hospitals, run into the judicial hesitancy to compel a coordinate branch of government to allocate vast resources to a health priority-a problem which would plague enforcement of the right-to-life principle.

A common law right of access based on the public trust theory would, however, impose a tremendous fiscal burden on nonproprietary hospitals. That this is so does not automatically exclude consideration of the theory or mean that the burdens are unreasonable. For present obligations imposed on hospitals have created fiscal burdens that have generally been overcome without serious adverse consequences. The common law duty to handle emergency cases ${ }^{79}$ impels the expenditure of funds to service poor patients. Traditional regulatory controls placed upon hospitals also require expenditures: code requirements with regard to fireproofing, building specifications, equipment, and personnel may all impose heavy financial burdens in order to protect the public interest; even the regulation of staff admissions and ousters may provoke expenditures in setting up hearings on qualifications or misconduct. $^{80}$ Yet fiscal integrity remains an important consideration in determining whether a hospital should be compelled to service indigent patients. The economic burden might be great enough to invoke complaints of an unconstitutional "taking"; at the very least, the expense would have a substantial enough impact on a hospital's ability to function to warrant careful consideration. These factors assume even greater importance when it is considered that hospitals, unlike govern-

\footnotetext{
${ }^{78}$ Of course, some inroads on hospital admissions policies have already been made with regard to precluding racial discrimination. See, e.g., Simkins v. Moses H. Cone Memorial Hosp., 323 F.2d 959 (4th Cir. 1963); Eaton v. Grubbs, 329 F.2d 7 ro (4th Cir. 1964).

" See pp. 909-913 supra.

${ }^{80}$ See Sussman v. Overlook Hosp. Ass'n, 95 N.J. Super. 4r8, 23 I A.2d 389 (App. Div. 1967).
} 
mental bodies, do not possess the taxing power necessary to distribute "public interest" burdens over the general population. Thus, unless third-party payments from private insurers or government benefit programs covered all patients, a situation which clearly does not exist, the fiscal burdens on private hospitals stemming from indigents' care would be a very real factor to consider in shaping any emerging common law obligation.

Many voluntary hospitals would doubtless contend that a duty to accept indigent patients means bankruptcy. Indeed, such institutions already contend that in many locales they are in dire fiscal straits. ${ }^{81}$ It might be argued that these "nonprofit" hospitals are not really in danger of insolvency, and that the effect of the proposed common law obligation would simply be to realign their priorities toward basic patient care. According to this theory, modern charitable hospitals divert resources needed for patient care toward mindless expansion, expensive and underutilized equipment, research, and teaching. ${ }^{82}$ It might also be argued that a common law right of access would simply redirect nonprofit "charitable" institutions to fulfill their original purposes. ${ }^{83}$ Given the essential public function which they would be performing, it would then be inconceivable that "government" could allow the hospitals to flounder. But there are several reasons why the threat to fiscal integrity from a common law right of access cannot be ignored.

In the first place, even if reallocation of internal resources rather than insolvency would be the product of the proposed common law obligation, courts must be hesitant to mandate that result. There is no assurance that resources for patient care would not be diverted from needed expansion or necessary research. Arguably, "[h]ospitals should to a great extent be free to allocate their money according to a scheme which they in good faith believe will produce the greatest good for the greatest number of patients." ${ }^{\text {" N }}$ Nor can it be automatically assumed that government would fully subsidize the research and teaching potentially affected by added patient care obligations. Second, the added fiscal burden imposed by a common law right of access would probably cripple, and not just hamper, some hospitals. An urban institution which services a primarily poor population would not have the needed budgetary flexibility to absorb the burden of indigents' care. Without a comprehensive system of third-party payments-a system which Medicaid and Medicare do not yet provide -insolvency would presumably result.

One "solution" would be to limit the common law "public service" obligation to provision of an economically feasible volume of services. This formula, however, obviously involves extensive problems of judicial administration, and courts must

\footnotetext{
${ }^{81}$ See Catholic Medical Center v. Rockefeller, 305 F. Supp. 1256 (E.D.N.Y.), 305 F. Supp. x268 (E.D.N.Y. x969), vacated and remanded, 397 U.S. 820 (1970).

${ }^{83}$ See Medical Empires, Bull. Hentrir Policy AdvisonY Council, Nov.-Dec. 1969; The Trouble with Empires, Bull. Health Policy Advisory Councin, Apr. 1969.

${ }^{88}$ Note, Working Rules for Assuring Nondiscrimination in Hospital Administration, 74 YALE L.J. I5I, $156 \mathrm{n} .32$ ( 1964$)$.

${ }^{84}$ Scarce Medical Resources, supra note $4 \mathrm{I}$, at $69 \mathrm{r}$.
} 
be ready to deal with the complex issues raised. The problems arise as soon as the hospital can no longer admit patients strictly according to health needs. Would economies then be accomplished by limiting the volume of patients admitted or by restricting the type of services provided? When does hospital expansion become appropriate? Could a hospital restrict usage of expensive equipment (such as renal dialysis machines) to paying patients who would make the equipment selfsustaining? Could availability of a fixed percentage of beds, say thirty per cent, for indigent patients be required? What income level would constitute indigency for purposes of the common law definition? Could a hospital satisfy its obligations by adopting sliding fee schedules, or must services be absolutely free to persons below a certain income level? Indeed, when is a medical facility sufficiently imbued with public interest to trigger a public service obligation? Do neighborhood health centers or group practices have the same essential characteristics as hospitals? These various administrative problems and issues indicate that courts would have to struggle to monitor a standard which varied the obligation of hospitals toward indigent patients according to the economic viability of particular institutions. Yet imposition of a crippling financial burden might be both unwise and constitutionally suspect. $^{85}$

A second "solution" would simply utilize most hospitals' immediate ability to spread costs by increasing charges to nonindigent patients. The issue then becomes whether the burden of providing for poor patients should be absorbed by the segment of the public which is unfortunate enough to undergo hospital care and which is already paying exorbitant fees. Or should the burden be distributed over the general population via tax mechanisms? If the bulk of hospital payments come from government or other third-party payors, perhaps the costs immediately attributable to paying hospital patients are ultimately absorbed by the general population. Until that is clear, there are considerable hazards in imposing a common law obligation upon hospitals to treat all members of the public. Yet the status quo-a dual system of health care-is so distasteful that, despite the risks, it is well worth the effort of an enterprising court to shape a legal obligation to care for indigent patients. By clarifying the public nature of the modern hospital and indicating its concomitant obligation to provide services according to health need rather than wealth, the judiciary would merely redirect the hospital toward its intended function $\rightarrow$ satisfaction of the community's health needs.

\section{III}

\section{Statutory Provisions}

\section{A. Hill-Burton}

In the Hospital Survey and Construction Act of $1946,{ }^{86}$ popularly known as the

\footnotetext{
${ }^{85}$ Cf. Findlay v. Board of Supervisors, 72 Ariz. 58, 230 P.2d 526 (195I).

${ }^{80} \mathrm{Ch} .958,60$ Stat. 1040.
} 
Hill-Burton act, Congress established a program to provide funds for local hospital construction and modernization which has prevailed to the present day. The program is administered by the Health Services and Mental Health Administration of HEW, which allocates funds to states which have submitted satisfactory "plans" conforming to federal regulations. Of primary interest here are certain provisions of the act and regulations which relate to services for persons unable to pay therefor, for it has been argued that these provisions provide a legal basis for compelling facilities constructed with Hill-Burton money to care for indigent patients. ${ }^{87}$

The basis for the argument is subsection 2grc(e) of the act, which authorizes regulations which would require grant applicants to assure that

there will be made available in the facility or portion thereof to be constructed or modernized a reasonable volume of services to persons unable to pay therefor, but an exception shall be made if such a requirement is not feasible from a financial viewpoint. 88

The implementing regulations read in pertinent part as follows:

The facility will furnish below cost or without charge a reasonable volume of services to persons unable to pay therefor. As used in this paragraph, "persons unable to pay therefor" includes persons who are otherwise self-supporting but are unable to pay the full cost of needed services. Such services may be paid for wholly or partly out of public funds or contributions of individuals and private and charitable organizations such as community chest or may be contributed at the expense of the facility itself. In determining what constitutes a reasonable volume of services to persons unable to pay therefor, there shall be considered conditions in the area to be served by the applicant, including the amount of such services that may be available otherwise than through the applicant. The requirements of assurance from the applicant may be waived if the applicant demonstrates to the satisfaction of the State agency, subject to subsequent approval by the Secretary, that to furnish such services is not feasible financially . ...89

Although it appears that very few facilities have opted out of the obligation by demonstrating financial weakness, it also appears that "no mechanism has been established within HEW to enforce the commitment, nor has HEW ever acted in this regard.".mo

As currently worded, the regulations contain too many loopholes to serve as an effective vehicle for assuring indigents' access to private hospitals. ${ }^{01}$ In the first

\footnotetext{
${ }^{87}$ For comprehensive and interesting discussions of Hill-Burton's relevance to poor populations, see two recent articles by Marilyn G. Rose, Deputy Director of the National Legal Program on Health Problems of the Poor: Hospital Admission of the Poor and the Hill-Btrton Act, 3 CLEARINGHovse Rev. I85 (1969); The Duty of Publicly Funded Hospitals to Provide Services to the Medically Indigent, 3 Clearingrouse Rev. 254 (1970).

${ }^{88} 42$ U.S.C. $\$ 29 \mathrm{Ic}(\mathrm{e})(2)(\mathrm{Ig} 64)$.

${ }^{80} 42$ C.F.R. $\$$ 53.III(b) (1970).

${ }^{00}$ Hospital Admission of the Poor and the Hill-Burton Act, supra note 87, at 192.

${ }^{01}$ One writer has suggested that the present regulations, in their permissiveness toward hospitals' means of satisfying the obligation to provide "free" care, are inconsistent with the act. See The Duty of
} 
place, services may be furnished either below cost or without charge. Any facility currently accepting Medicaid patients will contend, and probably legitimately so, that Medicaid reimbursement does not meet full hospital costs; these patients are therefore already being serviced "below cost." Second, the regulations explicitly state that the required services may be paid for out of public funds or may be contributed at the expense of the facility itself. Thus, hospitals receiving local welfare patients, or even Medicaid patients, are arguably fulfilling their obligations. Finally, there is the omnipresent opportunity for a facility to evade entirely a commitment to indigents by demonstrating financial inability to meet the burden. The act itself indicates in two different places that the financial integrity of institutions is not to be jeopardized by obligations to service the poor. ${ }^{92}$ At the very least, the exercise of this option by a hospital will place a substantial burden on litigators to pierce the bookkeeping veil surrounding hospital finances and show that services to indigents are feasible. Even then, a "reasonable volume" must be defined. Just as would be the case in administering a common law obligation to service indigents, there would be complex problems in assessing the hospital's ability to direct funds to the service of indigent patients. The one advantage under Hill-Burton is that there are administrative agencies-both HEW and the state administering agency-which are presumably equipped to appraise accurately the economic position of particular facilities.

\section{B. Medicaid}

Title XIX of the Social Security Act of $1965{ }^{93}$ commonly known as Medicaid, was intended "to make medical services for the needy more generally available." By guaranteeing reimbursement to providers for furnishing care to indigents, it

Publicly Funded Hospitals to Provide Services to the Medically Indigent, supra note 87, at 256. This argument is centered on the notion that "persons unable to pay therefor" must include medically indigent persons unable to meet any costs of care as well as persons able to meet partial costs either through Medicaid or personal resources, as well as on the idea that the free care provision was supposedly a central provision of the act. Id. at $26 \mathrm{r}$.

However, it is doubtful that Hill-Burton was intended to be of great importance to poverty communities. There was frank recognition throughout the legislative hearings that the bill's failure to provide for hospital operating and maintenance costs severely restricted its utility to poverty areas. See S. REP. No. 674,79 th Cong., Ist Sess. 6, I7-20, I90 (I945). The free care sections might have been added on the assumption, then, that applicants would be from relatively affluent areas which could shoulder the added expenses. At the same time, Congress added two specific indications of concern for the continuing financial integrity of recipient institutions. See 42 U.S.C. $\$ 2 \operatorname{rrc}(c)$ (rg64), 29re(f) (1946). Thus, if hospitals are in fact economically pressed in just meeting the differential between Medicaid reimbursements and actual costs, there is probably little hope of securing more "free" care under the act. However, the part of the regulations which permits private hospitals to meet their obligation through "public funds" is certainly suspect. The provision would be reasonable if applied strictly to governmental hospitals, where part of the Medicaid funds actually come from the same governmental source as operates in the hospital; but private hospitals should not be absolved of their obligation by payments from local governmental sources.

${ }^{92} 42$ U.S.C. $\$ \S 29 \mathrm{Ic}(\mathrm{e})(\mathrm{rg} 64), 29 \mathrm{Ie}(\mathrm{f})(\mathrm{rg} 46)$.

${ }^{98}$ Pub. Law 89-97, tit. I, \$ I2I(a), 79 Stat. 343.

${ }^{04}$ S. Rep. No. 404, 89th Cong., Ist Sess. 74 (I965). 
was thought that poor patients would obtain access to any facility and receive care previously denied. "The notion was that Medicaid would liberate the poor from bondage to a particular doctor . . . or charity hospital either owned by the state or having a charity contract with the state."95 A section of the act known as the "freedom of choice" provision ${ }^{96}$ assured recipients that services could be obtained at the facility of their choice, provided that the facility was willing to render services to Medicaid recipients.

To some extent Medicaid has in fact resulted in increased usage of health services by the poor. Particularly for specialty services such as dental care, people who had previously gone unattended sought and obtained medical assistance pursuant to Medicaid. ${ }^{97}$ But the increase in utilization has come primarily in numbers of patients, and not in any improvement or change in the quality of care or type of facility rendering services. "The poor remain in the same system as before-receiving charity medicine and stigmatized as such by receiving care from providers catering exclusively or substantially to those unable to afford mainstream medical care."18 Many fewer doctors than anticipated have agreed to take Medicaid patients and to subscribe to the provider terms set down by the Medicaid program. ${ }^{99}$ In New York City, for example, it has been estimated that only fifteen per cent of eligible practitioners have enrolled as Medicaid providers. Nor has the program caused a significant shift in location of providers; the ghettoes still suffer from a dearth of private physicians.

Various explanations have been advanced for Medicaid's failure to attract a sufficient number of physicians. Unrealistic fee schedules, delays in payment, and excessive paperwork or red tape have all been cited as explanatory factors. ${ }^{100}$ But whatever the actual cause, it is clear that the failure to enlist sufficient practitioners violates both the letter and the spirit of the Medicaid statute and regulations. Certainly, freedom of choice ${ }^{101}$ can never be a reality until an adequate number of Medicaid providers are available. Further, the regulations specifically require that fee structures be "realistic" and designed to enlist sufficient practitioners for the program; ${ }^{102}$ at least two-thirds of the practitioners in the state should be enrolled. ${ }^{103}$ Moreover, the state administering agency is responsible for assuring that the program is uniformly and continuously operating throughout the state. ${ }^{104}$ The overriding

\footnotetext{
${ }^{o r}$ Edelstein, Medicaid, in Materials on Hearth Rights Prepared for the Natronal Conference on Health Rights of the Poor 93 (National Institute for Education in Law and Poverty, 1970).

${ }^{\circ 6} 42$ U.S.C. $\$ 1396 \mathrm{a}(\mathrm{a})(23)$ (Supp. IV, I969).

${ }^{97}$ See Medicaid: The Patchwork Crazy Quilt, 5 Colum. J. LAw \& Soc. Pros. 62, 66 n.37 (1969).

${ }^{08}$ Edelstein, supra note 95.

${ }^{90}$ See Medicaid: The Patchwork Crazy Quilt, supra note 97, at 76-77.

${ }^{100}$ Id. at $77-79$.

${ }^{202} 42$ U.S.C. $\$ 1396 a(a)(23)$ (Supp. IV, 1969).

${ }^{103}$ HandbooK of Public Assistance Administration $\$ 5320.1$ (Supp. D I966). See also id. $\$ \$ 5144$, 5340,5360 , regarding fee structures.

${ }^{108} 1 d . \$ 5330.3$.

106 $7 d . \$ \S 2230(2),(5),(6), 2280$.
} 
objective, according to the regulations, is to secure care for poor persons to the extent available to the general population. ${ }^{105}$

The problem, then, is not in finding legal bases for arguing that the Medicaid program is failing to fulfill its obligations but rather in finding remedial channels and in shaping specific relief. The two principal defects appear to be "unrealistic" fee schedules and administrative delays in processing bills. As to the former problem, it is simply not palatable for Medicaid patients to try and raise physicians' incomes without also provoking over-all changes in the health care delivery system; ${ }^{100}$ Medicaid has already contributed markedly to an inflationary spiral of medical costs. And providers have demonstrated their own capacity to lobby for increased reimbursements. ${ }^{107}$ The second objective-improvement of administrative efficiencyis a desirable goal and one which might be expanded to cover other aspects of Medicaid which affect poor persons. ${ }^{108}$ But ending delays and inefficiencies is not an easily attainable objective, either through judicial or administrative channels. Experience with welfare administration has indicated that bureaucratic intransigency is not subject to easy rectification. ${ }^{109}$ Thus, a state agency may be ordered to process applications or bills within a defined period, but there is no effective sanction for nonconformity with the order other than the unrealistic option of cutting off federal contributions to the state program. Similarly, a state may be ordered to enroll at least two-thirds of its practitioners as Medicaid providers, but there is no apparent way of assuring that the desired result will be accomplished.

\section{ConcLusion}

The ultimate objective is adequate health care readily available for all citizens. The preceding analysis indicates that litigation has a role to play if the courts will be innovative in shaping new rights for impoverished citizens and new remedies to meet the extraordinary challenge of providing expensive facilities and manpower. Recent Supreme Court decisions do not furnish much basis for optimism. Reliance will have to be placed on the ability of both the Constitution and the common law to challenge social injustice in whatever limited ways legal remedies are suitable to solving massive economic and political problems. A genuine shift in governmental priorities is likely to come only through political channels.

\footnotetext{
${ }^{105} T d . \$ 5340$.

${ }^{100}$ Cf. Report of the Task Force on Medicaid and Related Programs 36-39 (x970).

${ }^{107}$ See Catholic Medical Center v. Rockefeller, 305 F. Supp. I256 (E.D.N.Y.), 305 F. Supp. 1268 (E.D.N.Y. I969), vacated and remanded, 397 U.S. 820 (1970).

${ }^{103}$ For example, litigators might seek to streamline the procedures for processing applications and handling administrative appeals.

${ }^{100}$ See generally Murphy \& Wexler, Alternatives to King v. Smith in Enforcing State Compliance with the Social Security Act, 3 CLEARINGHouse Rev. 6I (Ig69).
} 